\title{
DIFFERENTIATED REGULATION: THE CASE OF CHARITIES
}

\begin{abstract}
The increasing number and influence of charities in the economy, evidence of mismanagement, and the need for information for policy-making, are all reasons for establishing charity regulators. Public interest and public choice theories explain charity regulation which aims to increase public trust and confidence in charities (and thus increase voluntarism and philanthropy), and to limit tax benefits to specific organisations and donors. Nevertheless, regulation is resource intensive, and growing pressure on government budgets requires efficiencies to be found. This paper proposes regulation differentiated according to charities' main resource providers, to reduce costs and focus regulatory effort, and provides a feasible segmentation.
\end{abstract}




\section{DIFFERENTIATED REGULATION: THE CASE OF CHARITIES}

\section{Introduction}

In response to "scandals and doubts about public trust and confidence" (Connolly \& Hyndman, 2013, p. 946), there have been calls for greater accountability and transparency from organisations formed for the public benefit. Indeed, a number of jurisdictions have recently established charity regulators (for example, New Zealand's Charities Commission and Singapore's Commissioner of Charities in 2006, the Charity Commission for Northern Ireland in 2010, and the Australian Charities and Not-for-profits Commission (ACNC) in 2012). ${ }^{1}$ Some calls for regulation are also from those concerned that public policy would otherwise be undertaken in a vacuum, due to a lack of knowledge about the size and reach of the charitable sector (for example, Ferguson, 2005; Lyons, 2001).

This research focuses on regulation designed to increase the accountability and transparency of organizations that are defined in law as charities, in particular through requiring financial reporting. ${ }^{2}$ In many jurisdictions, there are specific benefits available to registered charities, including exemption from taxation on income (specifically surpluses), reduced state and local taxes, preferential access to government and philanthropic funds, and taxation concessions for donors (Abramson, Salamon, \& Steurle, 2006; Breen, Ford, \& Morgan, 2009; Smith, 2012). Governments have good reason to support charities and philanthropists, as these actors can reduce the burden on state funds, increase community resilience, and encourage civil society (Hyndman \& McMahon, 2011; Mayer \& Wilson, 2010; Salamon, 1990). Nevertheless, governments also regulate to restrict the organizations that can continue to avail themselves of these taxation and other benefits, to those whose purposes and activities would maximise governments' policy goals and, note Desai and Yetman (2005), to reduce abuse of the tax-exempt status. In addition, given the reports of staff acting opportunistically with governments' and donors' funds, and inaccurate reporting or manipulation of financial disclosures (Desai \& Yetman, 2005; Gibelman \& Gelman, 2004; Hofmann \& McSwain, 2013; Leone \& Van Horn, 2005; Phillips, 2013; Sinclair, Northcott, \& Hooper, 2014; Yetman \& Yetman, 2012), calls for increased regulation are unsurprising. Various regulatory practices (including publication of financial statements) may increase public trust and confidence in this sector; and potentially increase donations of time and money (philanthropy) (Breen, 2009; Keating \& Frumkin, 2003).

1 As further noted, the New Zealand Charities Commission has undergone modification since its establishment and the ACNC (Repeal) (No.1) Bill (2014) signals the demise of that regulator (Saj, 2014)

2 Some regulators (for example, New Zealand) make the financial statements publically available (and in the US, a shortened form (Form 990) can be accessed by the public) (Phillips, 2013). 
Yet, the economic downturn from 2009 and general pressure on government budgets has forced charity regulators to cut costs (Mayer \& Wilson, 2010) and find efficiencies. Further, regulatory burden ('red tape') on charities is the reason cited for the demise of the Australian ACNC as that government tries to reduce compliance costs (Australian Government Department of Social Services, 2014). ${ }^{3}$ However, the need for regulation requiring greater levels of disclosure and transparency by charities is self-evident, due to significant government and public support of charities, the levels of fraud and earnings manipulation in the charitable sector (Desai \& Yetman, 2005; Hofmann \& McSwain, 2013; Leone \& Van Horn, 2005; Sinclair et al., 2014; Yetman \& Yetman, 2012) and the effect of public policy on the charitable sector (and vice-versa). While self-reporting/self-regulation is one way to reduce regulatory burden, nevertheless low levels of compliance make this tactic unlikely to increase regulatory efficiency (Australian Government Department of Social Services, 2014). Co-regulation has had some success in Canada (Phillips, 2013), although innovative approaches are few and far between in the charitable regulation space.

Thus a conundrum presents itself - how can we increase public trust and confidence in the charity sector by efficient accountability and transparency? At a time when public scrutiny and demands for accountability and transparency are increasing, developing efficient regulatory options for this sector is especially necessary (Ferguson, 2005; Gaskin, 1999; Gibelman \& Gelman, 2004; Phillips, 2013; Saj, 2014). It is the objective of this paper to present a case for differentiated regulation as one step towards meeting these demands. This case is underpinned by theories that explain the rise of the charitable sector, rationales for regulation, and close analysis of empirical data to support the argument.

This research asks: how can the population of registered charities be segmented to reduce the cost (and impost) of regulation as a step towards greater regulatory efficiency? New Zealand data utilised in this research supports the proposition that not all of the charities registering with their regulator in order to avail themselves of benefits require government oversight, as their primary resource providers (principals) are in a position to exercise oversight responsibilities of these charities (agents). We posit that, instead of spreading reduced regulatory resources ever-more thinly, differentiated regulation provides a useful strategy for charity regulators to focus regulatory effort, increase effectiveness and reduce costs. Differentiated regulation requires an effective segmentation of charities according to their main resource providers (i.e. the stakeholders who are likely to be most interested in their performance) with registration only for those charities whose members/close

\footnotetext{
3 Yet, Saj (2014) notes the political motivation behind this, in that the majority of submissions were against
} closing the ACNC's operations, but the government is pressing ahead. 
stakeholders provide the majority of resources, and regulation with closer monitoring for those whose main resource providers are "the public", that is, who are diverse and for whom the costs of monitoring are high (Williams, 1984). In this research, we demonstrate (using cluster analysis) that such segmentation can be achieved, and that regulation could benefit from such an approach. Such differentiation upholds specific economic theories explaining why these organisations form and operate. Accordingly, the paper adds to the literature through exploring an option for regulation that is supported by theory, and is underpinned by an imperative of transparent reporting and disclosure.

The remainder of this paper is organised as follows. In section 2 we discuss theories explaining why charities form and operate. In section 3 we review the arguments for regulation and introduce differentiated regulation in section 4 . In section 5 we present our empirical analysis to demonstrate the feasibility of segmenting charities consistent with differentiated regulation. Section 6 concludes the paper with discussion of our results and identification of opportunities for further research.

\section{The Charities Sector}

The rise of charity regulators is related to the increasing number and reach of nonprofit organizations in general and charities in particular, ${ }^{4}$ especially as governments increasingly contract with charities to deliver social services (Hyndman \& McMahon, 2011; Mayer \& Wilson, 2010). This section overviews the major economic theories describing why charities emerge and therefore who their main resource providers will be. These are: market failure, government failure, voluntary failure, and contracting for 'trust goods'. ${ }^{5}$ In the last part of this section, we highlight the strident calls for regulating these organizations.

\subsection{Some theories explaining the rise of the sector}

Market failure and government failure can explain why organizations form which deliver public/ collective goods and services and do not distribute profits to owners. These organizations are likely to receive funds from donors, governments and, to a lesser extent, payment from service recipients.

Rose-Ackerman (1986) argues that market failure occurs when goods can be delivered at a lower net cost (after the cost of contracting) by nonprofit rather than for-profit organizations. This will

4 Economic theories refer to nonprofit organizations in general, but this paper focuses on organizations defined in jurisdictions as charities, a subset of the nonprofit sector.

5 We recognize that other theories have been devised to explain the relationship between the nonprofit sector and government (for example, social origins theory and interdependence as in Salamon, 1990, 1995), and also the rise of social entrepreneurs as differentiated from business entrepreneurs (Young \& Grinsfelder, 2006). Nevertheless, the paper uses four main economic theories in this preliminary analysis. 
occur when the nonprofit organization is prepared to earn less than the cost of capital, and/or draw on voluntary labour donations. Nonprofit providers cater to those who cannot afford to pay the market price and thus can supplement the work of for-profit providers who will service only those clients who can and are willing to pay the market price. ${ }^{6}$ They will seek funding from donations (including bequests and sponsorships) and, because market failure also occurs in relation to the provision of public or collective goods, government will also be a major resource provider. In respect of public goods, for-profit organizations are not inclined to deliver these goods owing to free-riders. Government can reduce such market failure through taxes and incentives to encourage service provision by others (Weisbrod, 1988, 1989).

While governments may use taxes and incentives to remedy market failure, nevertheless, when government is forced to step in as a provider or major funder, the services it supplies tend to be homogeneous, not cognisant of diversity in communities, and hence government failure can occur. ${ }^{7}$ Nonprofit organizations emerge to reduce government failure by meeting the diverse needs of specific (heterogeneous) communities (Weisbrod, 1989), drawing on resources from government, donations, bequests and sponsorships.

The extent to which nonprofit organizations can continue to operate depends on such external funding and, without sufficient patronage or government support, they will fail (Salamon, 1987 terms this "voluntary failure"). Studies utilising this theory include Sutton, Baskerville and Cordery (2010) who analysed the failure of a national charity as it lost legitimacy with the donating public and government. Robbins and Lapsley (2008) also utilised the theory to analyse voluntary failure in the Irish hospital charitable sector, citing the reduction in resourcing as inflation impacted endowment funds, donations fell and costs rose.

A further reason for the rise of nonprofit organisations is provided by Ben-Ner (1986). When information asymmetry limits consumers' ability to assess service quality, they are more likely to form their own organizations to ensure quality, or transact for these 'trust goods' with a nonprofit organization (Ben-Ner, 1986; Hansmann, 1986). Trust good transactions include, for example, when an adult child commits their parent with dementia to an aged care facility. Here, they cannot observe the quality of care, nor may the parent be able to adequately inform them. In these and similar situations, member management of nonprofit member-based organizations signals that the services can be obtained at a cost and quality that the members prefer (Cleveland \& Krashinsky, 2009). Further,

6 For example, for-profit organizations 'cream-skimming' or servicing clients that present simple, profitable cases is a problem endemic in health care.

7 That is, government fails to deliver public or collective goods that match demand. 
Cleveland and Krashinsky (2009) show that, in well-developed markets, these nonprofit providers also provide higher quality care than for-profit providers. While they may be effective, yet Weisbrod (1989) notes that these organizations' managers have less incentive to be efficient than managers in forprofit businesses, therefore they require greater monitoring of their financial and social performance. The main resource providers - members who have formed and who fund the organisation - are best placed to undertake such monitoring (Cleveland \& Krashinsky, 2009).

From this brief explanation of market failure, government failure, voluntary failure and trust goods (theories which are well described in the literature), government support is now presented.

\subsection{Support through taxation relief}

In addition to providing services in basic areas, such as health and social services, the charity sector includes organizations that enrich cultural diversity within society (for example, arts organizations), contribute to the community (for example, environmental organizations) and in so doing, develop social capital within communities (Bryce, 2005). Governments must decide which of these non-market additions to public and collective goods they should support and how.

Fries $(2003$, p. 8) notes that charities provide opportunities for "citizens to contribute to the public good on their own initiative". Citizens may offer funds, voluntary labour, labour at a reduced cost, or donate goods, thus enabling a nonprofit organization to reduce its service costs (James, 1987). When government is also a funder of these goods, it will also seek to encourage philanthropy and thus reduce demands on it to provide more funding. Philanthropy should grow when there is increased public trust and confidence in these charities (Williams, 1984), which can occur through the provision of financial reports (Gordon \& Khumawala, 1999; Sinclair et al., 2014).

A major tax benefit often extended to charities is an income tax exemption on surpluses from trading activities and income from investments. Some argue that tax-exempt bodies potentially enjoy a competitive advantage over for-profit businesses; this advantage is further extended if they use volunteers to deliver goods and services (Dalton \& Casey, 2008). ${ }^{8}$ Yet, nonprofit trading concerns could be disadvantaged by their limited access to finance and credit compared to for-profit and public sector organizations. Further, a lack of horizontal equity exists between the nonprofit, for-profit and public sectors, as nonprofit public sector organizations are both tax-exempt and also potentially have better access to credit and finance. While the Australian Productivity Commission (2010) argued there was no benefit in organizational type when there is an aim to maximise surplus, nevertheless income tax

8 This could be deemed unfair competition; nevertheless, the argument is void if there are no for-profit participants (as occurs when market failure is present). 
exemption is often viewed as appropriate for nonprofit organizations with a public benefit intent rather than profit maximization.

\subsection{Calls for regulation}

Financial and governance scandals have seen increasing calls for charity regulation (Ferguson, 2005; Gaskin, 1999; Productivity Commission, 2010). For example, wrongdoing in charities includes theft, misconduct, excessive compensation, and mismanagement of resources (Desai \& Yetman, 2005; Gibelman \& Gelman, 2004; Hofmann \& McSwain, 2013; Leone \& Van Horn, 2005). It is unsurprising, therefore, that declining public confidence in charities (due in part to such scandals) has led to calls for enhanced charity accountability and regulation (Gaskin, 1999; Gibelman \& Gelman, 2004).

Due to the sensitivity of such scandals, regulators have responded by increasing the regulatory scrutiny of the charity sector, including requiring charities to produce financial reports if they are to enjoy taxation concessions and other benefits (Mayer \& Wilson, 2010). Nevertheless, the disparity in charity size is one factor that makes regulation of charities a 'complex problem' (Mayer \& Wilson, 2010). For example, Mayer and Wilson (2010) and Palmer (2013) note that regulatory disclosure may be burdensome for small charities (compliance costs were a strong argument against the ACNC, Saj, 2014). Enforcement barriers are a further issue; including regulators' constrained resources (Mayer \& Wilson, 2010). Design of the appropriate form of regulation is therefore challenging.

\section{Arguments for Charity Regulation}

The number of theories of regulation and the fact that the need and imposition of regulation is both contextually and temporally specific, make discussions of regulation complex. While neoclassical theorists discourage public regulatory intervention, the recognition that markets are not perfectly efficient has given rise to two rationales for regulation - public interest (as argued by Stigler, 1971), and public choice theory (as argued for by Peltzman, 1976).

The public interest theory of regulation asserts that regulation is necessary to deal effectively with substantive resource distribution problems (Christensen \& Lægreid, 2006). Public interest theory argues that business operations prefer their private interests rather than the public interest and that, due to information asymmetry, regulation is needed to protect the public interest. This theory specifically acknowledges market failure (Chalmers, Godfrey, \& Lynch, 2012). Regulation may be used to reduce the likelihood that a monopoly will under-provide a good or service. A regulator may also facilitate activities to address information asymmetries and assist fair distribution of resources (Williams, 1984). In the charity case, for example, a fundraising regulator may monitor whether these 
donations are applied appropriately to a charitable purpose and thus, improve confidence in the 'donor market' (Breen, 2009; Cordery, 2013).

Public interest theory suggests that government may also regulate to restrict entry to ensure public safety and quality, often building (or supporting) a market to efficiently establish prices and quality (as could happen for a donor market) (Chalmers et al., 2012; Christensen \& Lægreid, 2006; Stigler, 1971). Mechanisms for evicting or punishing miscreants are also tools of restrictive entry regulation and (as can be seen in the charity space) much effort of new regulators is applied to registration and compliance with entry restrictions. Regulation mandating organizational disclosure of specific items (especially financial statements), is less interventionist than regulation that restricts entry to a particular market, and is a common policy tool (Breen, 2013; Solomons, 1978). Financial reporting regulation within the securities markets originated as a reaction to insufficient voluntary disclosure to maintain an internationally efficient marketplace (Solomons, 1978). By restricting incentives and opportunities for reporting manipulation, regulators aim to restore market confidence, encourage investor participation, and improve issuers' governance (Solomons, 1978). Such regulation for disclosure is likely to be in the public interest, but will require regulated organizations to collect and process new information, increase information dissemination and accept assurance costs. Charity regulators take a similar approach, but often reduce the reporting burden on smaller charities in recognition of those costs (Cordery, 2013) (see also Table 1).

Public choice theory asserts that most regulation is merely a tool for addressing perceived problems, and that often the promise of regulation serving the public interest is not realised. This is due to rational ignorance, the self-interest of the politicians and public servants who regulate, and the possibility of regulatory capture (Christensen \& Lægreid, 2006). Peltzman (1976) notes that rational regulators will seek to maximize political returns, rather than purely economic returns. Extrapolating this argument to the charities sector suggests that charity regulation may be perceived as "good" politically, especially when government financially supports charities, but such regulation could increase charities' costs and change resource flows without necessarily increasing donors' trust and confidence. Therefore, public choice highlights the necessity for regulatory efficiency so that regulatory costs do not exceed benefits. Regulators need adequate funding, if both their law-making and enforcement roles are to be effective.

"Governments regulate charities in a variety of ways and through a variety of government agencies" (Mayer \& Wilson, 2010, p. 689). This is true of fundraising (for example, Breen, 2009) as well as organizational regulation, which is the subject of this article. For example, the United States (US) regulator is the Internal Revenue Service (IRS), as is the tax department in Canada. However, in 
England and Wales, the regulator is an independent organization, while in other countries it is within another government department (See Table 1). This is a structural decision which may be informed by the theoretical motivation to regulate, but also by historic structures in particular countries (for example, Irvine \& Ryan, 2013).

Government regulators frequently require charities to register, file returns, and be subject to audit on a random basis (as presaged by Solomons, 1978). Further, some regulators choose to respond to complaints from the public through audits and enquiries. However, recent reports show that the US regulator, the IRS, examined merely $1.36 \%$ of returns from tax-exempt organizations in 2011 (ten years earlier it was as low as 0.29\%), while the Charity Commission of England and Wales reported an audit rate of $0.33 \%$ (Breen, 2013). Since then, budget cuts have forced a re-assessment of regulatory activity. Yet Simon (1995) notes that, when charity regulators limit their audit activity in order to reduce regulatory costs, non-compliance rises. As an example of the costs of regulation, Table 1 shows a summary of the cost data from seven different countries that currently operate a charities regulator.

\section{[INSERT TABLE 1 HERE]}

Table 1 shows that the costs of emergent regulators (e.g. Australia) is high due to their establishment phase, while the regulators in England and Wales, New Zealand and Scotland operate on US\$192-208 per registered charity. ${ }^{9}$ Nevertheless, all have suffered budget cuts. To respond to shrinking government budgets, Mayer and Wilson (2010, p. 527) suggest that "options that look instead to self-regulation by charities or their supporters are therefore attractive". Philips (2013) suggests 'polycentric' regulation, so government regulation is augmented by the potential oversight of self-regulation, or third parties which publish ratings or other data for donors. She notes in the Canadian context, that such a move has been marked by politicization of the regulation, but that a sector-based certification tool has potential.

Freeman (1984) agreed that stakeholder management can reduce the need for government regulatory activity, and Phillips (2013) argues this should increase the public availability of information. Nevertheless, private individuals (stakeholders) may lack "standing" (the legal ability to challenge charities through the courts) and be unable to manage if a regulator was unable or unwilling to act (Mayer \& Wilson, 2010). Only members of charities and trustees or directors who have legal standing could be expected to regulate the charity directly (Mayer \& Wilson, 2010). From the theory

9 Table 1 compares the direct costs of each regulator as disclosed, but it is recognized that these will differ due to the breadth of each regulator's responsibilities, the stage of its development and also undisclosed indirect costs. 
analysed above, members were identified as having a particular interest in the charities they establish and support (Ben-Ner, 1986; Weisbrod, 1989). How, therefore, can regulatory reform draw on such legally empowered parties to increase efficiency?

\section{Differentiated Regulation}

Regulatory reform is a key aspect of New Public Management, with early reformers seeking to 'roll back the state' and, more recently, to ensure better regulation (Christensen \& Lægreid, 2006). This has also led to new means of regulation: using different institutional frameworks and alternative regulatory practices (Hansen \& Pedersen, 2005). These alternatives to traditional approaches include co-regulation and self-regulation (as found in Canada in Phillips, 2013), targeted taxes, and differentiated regulation (Hansen \& Pedersen, 2005). An example of the latter is the regulators seeking to introduce higher standards for buildings or carbon emission differentiating between new buildings or vehicles and old ones through taxes, standards or disclosure regulations. Vintage-differentiated regulation (grandfathering) holds newly constructed facilities and vehicles to a higher quality than preexisting facilities (Gruenspecht, 1982; Stavin, 2006). ${ }^{10}$

Differentiated regulation may be observed in disclosure exemptions for smaller charities, for example in England and Wales and in Australia (see Table 1). In respect of ownership type and resource providers, New Zealand provides an example of differentiated regulation, as for-profit electricity distribution businesses are required to report against specific price and quality metrics to the regulator, and yet consumer-owned electricity distribution businesses are exempt from this regulatory reporting (Commerce Act, 1986 s.54D). This exemption from reporting is provided due to the ability of consumer-owners to monitor the prices and quality of their own electricity distribution business in the manner described by Ben-Ner (1986) in respect of trust goods.

Thus, differentiated regulation allows government to scan the field and require regulation of a selection of organizations, or to regulate some participants differently from others. This occurs in the example of the electricity industry in New Zealand, or as can be seen in Table 1 in England and Wales where some charities are excepted and some exempted, and in a number of jurisdictions where smaller charities are not required to file financial statements. In the charities space, joint monitoring by both regulators and stakeholders may be an option (Breen, 2009; Phillips, 2013). For example, it is

10 Differentiated regulation may also be used to open a market (to reduce a cartel and therefore as the antithesis of entry restriction) and is often used in the telecommunication and electricity industries to encourage greater competition (Peitz, 2005). Here, an asymmetry between operators with significant market power and those without is recognised by forcing major market players to provide newcomers with access to a network at prices the regulator sets, to increase access and competition (Peitz, 2005). 
suggested that charities relying on grants and/or donations from the general public (stakeholders) are more likely to file their financial statements with the regulator earlier (Reheul, Caneghem, \& Verbruggen, 2014) and to subject their financial statements to audit (Kitching, 2009). While Weisbrod and Dominguez (1986) and Posnett and Sandler (1989) found that significant donors do analyse financial statements before donating, nevertheless Verbruggen, Christiaens and Milis (2011) argue that donors may not be as interested in financial reporting as a government funder, raising questions as to the ability of a diverse public donor group (who is not legally empowered) to monitor effectively.

If the costs of regulation are high, but there is no improvement in public trust and confidence, then it may be well-intentioned (consistent with public interest) but ineffective, or simply be a tool to promote the interests of politicians/regulators without necessarily being intended to be effective (as argued by public choice theory). In either case, tools to increase the efficiency and effectiveness of regulation should be considered. We propose differentiated regulation as an effective measure. This could be a differentiation along similar lines to New Zealand's electricity redistributors (with lower levels of reporting) or by requiring certification (self-regulation) or third party rating systems (as outlined by Phillips, 2013). ${ }^{11}$ The particular choice of differentiation would be context-dependent.

While charity regulators most commonly differentiate regulation according to charity size (see Table 1), we hypothesize instead that the beneficial effects of regulation (for example, on public trust and confidence) will be experienced by some charities more than others. These will be the charities that are funded mainly by public donations (and arise to combat market failure as argued by RoseAckerman, 1986) and/or charities that receive funds for social services delivery (and arise to combat government failure as argued by Weisbrod, 1988). Further, as noted by Gordon and Khumawala (1999), donors that are distant from the charity (i.e. the public) are more likely to require financial statements before making a donation. We expect that charities with close donors will benefit from monitoring by their major resource providers - these may be member organizations with member managers (including deliverers of trust goods as argued by Ben-Ner, 1986; Cleveland \& Krashinsky, 2009), and those where voluntary trustees manage the charity (such as philanthropists who seek to redistribute wealth, or providers of infrastructure to communities and other nonprofit organizations). For these latter, the argument that trustees should monitor the charity is related not only to the reason for its establishment, but also the standing of trustees as relevant stakeholders.

11 As outlined by Kitching (2009), it is the larger charities that are followed by rating agencies, so this tactic is not suitable for the whole charities market. 
The following section describes an empirical study on New Zealand data which demonstrates the feasibility of segmentation and hence the practicality of differentiated regulation.

\section{Empirical Study}

\subsection{Context, costs and confidence}

The data used in this research is from the register of the New Zealand Charities Commission which was established as an independent Crown Entity in 2005 to accept registrations from 1 July 2007. At the time of the data collection in 2012, the Charities Commission had reached a 'normal phase' of operation following its start-up and registration of charities. However, the Commission subsequently was transferred into a government department and is now known as Charities Services. The regulator experienced a prolonged gestation. Concern had been expressed that organizations were being structured as charities in order to utilise tax benefits for tax avoidance, and various bodies recommended that a new regulator be established to register and monitor charities (these included: New Zealand Working Party on Charities and Sporting Bodies, 1989; Newell, 1997; Working Party on Registration Reporting and Monitoring of Charities, 2002). Furthermore, the lack of knowledge about the extent of government support to charities provided a strong impetus to charity regulation, as little data existed on charities' incomes and the levels of donations made to them (Slack \& Leung-Wai, 2007). Such information had the potential to be useful for policy-making as well as to restrict entry to charity-specific (tax) benefits.

The Charities Act 2005 enshrined in New Zealand Law the public benefit requirement and four heads of charity classified by Lord McNaughton in the well-known "Pemsel case" of 1891 (The Commissioners for Special Purposes of the Income Tax v. John Frederick Pemsel). This case has been foundational in decisions on appropriate charitable purposes and exemption from income tax in England and Wales (Gousmett, 2009) as well as New Zealand. The main purposes that define a charity are: the relief of poverty, the advancement of education, the advancement of religion, or other purposes beneficial to the community (Charities Act, 20052012 s.5(1)) with the overriding purpose of being in the public interest required to be demonstrated before the charity is able to register and receive the benefits thereof.

Following the register's establishment, the number of registered charities grew steadily to 27,000 as at $2013 .{ }^{12}$ Each charity is required to annually complete a standard format financial

12 All of these charities were automatically donee organizations. The cap on the donor rebates was removed in 2008 thus increasing rebates to a maximum of the tax paid by the donor (the rebate being a third of the donation, no matter the taxpayer's tax bracket). 
questionnaire and to file their financial statements for full information. They are also required to provide details of the charity's officers and other statistical information. The Charities Commission was established at a time of financial reporting change in New Zealand. As noted by Griffin, Lont and Sun (2009), the Accounting Standards Review Board required organizations to adopt NZ IFRS for reporting periods on or after 1 January 2007, and this included public sector and not-for-profit organizations as well as listed companies. Nevertheless, Release 9 (issued by the Accounting Standards Review Board, 2007) reduced the impost on small and medium-sized entities. While this exemption gave rise to various standards being used by those filing financial statements (rather than to follow a standard account format as in some jurisdictions), the requirement to file is universal (Sinclair et al., 2014).

The cost of this regulatory regime comprises the direct costs of the regulator, the compliance costs for the registered charities, and the welfare costs associated with the change in resource allocation resulting from operation of the regime. ${ }^{13}$ We have no information on the latter categories of costs but the on-going costs of the regulator are US\$192 per registered charity as shown in Table 1. In addition to the registration process, the regulator carried out 634 investigations in 2011 (2.8\% of registered charities) and 360 investigations in 2012 (1.48\% of registered charities) (Charities Commission, 2012) largely in response to complaints and referrals. In both years, more than 100 investigations remained uncompleted at year end.

It is unclear whether philanthropy has increased since the regulator has been established, however donation rebates to individuals have almost doubled from NZ\$119 million in 2005 (Slack \& Leung-Wai, 2007) to NZ\$203 million in $2011,{ }^{14}$ following the removal of the tax-cap on donation rebates which was likely to result in more participants in the 'donor market'. However, bi-annual surveys of public trust and confidence in charities evidence a decline in trust in charities - from a mean of 6.6 (out of 10) in 2008 to a mean of 6.0 in 2014 (Horizon Research, 2014).

In addition to donations, charities receive significant funds from government departments in the way of contracts and grants (these totalled NZ\$1.25 billion in 2006 against total government expenditure of NZ\$54.2 billion, (Department of Internal Affairs, 2007). (Total contracts and grants are likely to be higher, as this figure did not include second tier payments.) The data indicate that the significant government resources flowing into the sector by way of donation rebates and contracting

13 Charities pay NZ\$51.11 per annum if they file their annual statements and updates on line and NZ\$75.67 if they send in a paper version of updates and annual accounts (amounts ex-Goods and Services Tax). Charities with income of less than NZ\$10,000 pay no annual return fee.

142011 information downloaded from http://www.ird.govt.nz/aboutir/external-stats/revenue-refunds/ donations-rebates/ 1 December 2013. 
make it important to ensure efficient regulation. In the smaller charity sample, revenues ranged from nil to $\mathrm{NZ} \$ 5,329,334$, assets from nil to $\mathrm{NZ} \$ 8,305,951$ and liabilities from nil to $\mathrm{NZ} \$ 1,655,338$. In the medium-sized charity sample (with higher expenditures), revenues ranged from nil to NZ\$5,152,748, assets from nil to NZ\$25,156,933 liabilities from nil to NZ\$13,584,493.

We now turn to the question of whether the charities can be segmented into different 'types', for example, those funded mainly by donations (and arise to combat market failure as argued by RoseAckerman, 1986), charities that receive funds for social services delivery (and arise to combat government failure as argued by Weisbrod, 1988), member organizations with member managers (including deliverers of trust goods as argued by Ben-Ner, 1986), those managed by trustees, such as philanthropists who seek to redistribute wealth, and providers of infrastructure to communities and other nonprofit organizations.

\subsection{Analysis of "Types" of Registered Charities}

Market failure and government failure theories suggest that donative and social services charities are most likely to register with a regulator to receive tax benefits (see Rose-Ackerman, 1986; Weisbrod, 1988, 1989) and yet others may register as well, adding additional regulatory costs in a constrained environment. We used data from the New Zealand Charities' Register to determine whether, on the basis of revenue sources, the charities separated into different "types" which could be described based on their revenue, expenditures, assets and liabilities. We further were interested in whether or not any of these "types" could be called donative (as per Rose-Ackerman, 1986), social service charities (as per Weisbrod, 1988), membership charities (as per Ben-Ner, 1986), philanthropists seeking to re-distribute wealth, or providers of infrastructure to the community or other nonprofit organizations. Financial statements of a stratified random sample of 835 registered charities were extracted from the Register and analysed. ${ }^{15}$ The sample was stratified by the sector chosen by the charities from a list of twelve different sectors when they file their financial statements. ${ }^{16}$ Approximately half of the sample had expenditure of less than NZ\$40,000 (425) and the

15 The register included 21,156 organizations that had filed financial reports in November 2011, the date at which the register was accessed. Financial reports were progressively downloaded between November 2011 and January 2012.

16 Johns Hopkins University lists 12 different sectoral groupings for nonprofit organizations: culture and recreation, education and research, health, social services, environment, development and housing, civil rights, advocacy and politics, grant-making, philanthropic intermediaries and volunteerism promotion, international, religion, business and professional associations, unions and "not elsewhere classified" 
remainder (410) had expenditure greater than $N Z \$ 40,000$ but less than $N Z \$ 2,000,000.17$ The population from which this sample was drawn comprised $95.96 \%$ of the total register. We excluded large charities that comprise the balance due to a potential bias towards a business orientation.

Financial data filed by the charities in a pro-forma document was downloaded, along with their annual financial statements which they were required to file contemporaneously. These latter were separately entered into a spreadsheet to check the validity of the pro-forma data filed with the regulator. This was undertaken due to the known errors in this and similar filings with regulators and to enable analysis of the variety present in the reports filed (Cordery \& Patel, 2011; Crawford, Morgan, Cordery, \& Breen, 2014; Keating \& Frumkin, 2003). These organizations' revenues and expenditures were converted to ratios and analysed to enable comparisons. ${ }^{18}$ Charities with zero total revenue were omitted from the analysis, resulting finally in a data set of 803 charities.

We then used cluster analysis on the data set of 803 charities. Cluster analysis (specifically K-means cluster analysis) was used because we were looking for "types" or clusters of charities which met most, if not all, of the following criteria:

1. The different "types" generated by the statistical algorithm should, as much as possible be very different in terms of their dominant source(s) of revenue. That is, the different "types" defined by the statistical algorithm should provide groupings which are intuitively and meaningfully different, capturing the data's natural structure (Tan, Steinbach, \& Kumar, 2004).

2. Individual charities should, as much as possible, clearly belong to only one "type". That is, the mean percent of each revenue source should be very different from one charity "type" to another.

3. The different "types" of charities should each be very homogeneous. That is, the percent revenues should not vary a lot within each type.

(Salamon \& Anheier, 1992a, 1992b). Charities select their sector on their annual filing. These groupings were not useful to test the hypothesis as they did not separate out revenue flows and activities.

17 These dollar ranges were chosen as they corresponded to proposed reporting requirements. The population of the 'small' $(<\$ 40,000)$ segment was 11,282 and the 'medium' (>40,000 and $<2$ million) was 9,019 .

18 Each revenue category was expressed as a percentage of total revenue. Expenditures were expressed as a percentage of total expenditure and so on. 
4. The clustering algorithm should be reproducible. That is, when the cluster definitions based on the original data set of 803 charities are used in other data sets of charities, the charity "types" thus defined should also be very different, meaningful and homogeneous. For this reason, a second data set, a simple random sample of 296 further registered charities was used to verify the clustering algorithm.

K-means clustering is the most widely used clustering algorithm and assigns each case to one partitional cluster, rather than allowing over-lapping clusters nested or hierarchical sub-clusters (Tan et al., 2004). Further, K-means clustering is a complete clustering system rather than the partial clustering achieved by DBSCAN density-bound clustering algorithms (Tan et al., 2004). Nevertheless, K-means clustering has the limitation that the user chooses the number of clusters to be used. Therefore, we first used hierarchical clustering to determine the best cluster number for the 803 charities in the file. It suggested four clusters. K-means clustering was then performed on the 803 charities with 4, 5, and 6 clusters. The four cluster model included two clusters with 300 or more members, while the five cluster model included only one large $(300+)$ cluster. The six cluster model included one cluster with only 5 members, which would not allow for rigorous descriptive statistics. We therefore chose the five cluster model as the most useful for analysis.

We next extended the description of the five clusters beyond the revenue ratios, to include an analysis of expenditure, liabilities and assets. This allowed us to further describe our clusters and assess their suitability; finally, we validated the cluster algorithm (as recommended by Tan et al. 2004) with a second random sample of 296 charities (140 small and 156 medium-sized). For each of these 296 charities, the distance from the centroid of each cluster (from the analysis of the 803) was calculated, and the charity was assigned to the cluster whose centroid was closest. We then examined the data from this second data set to determine if they had a similar distribution of revenues, expenditures, assets and liabilities to the clusters in the first data set, and to examine whether the clusters in the second data set were distinct and homogeneous. We used one-way ANOVA and Post Hoc tests to see how the percent revenue means and standard deviations in this new sample met or did not meet our criteria for an adequate categorization of charities, and how the clusters in this second set resembled, or not, the clusters from the exploratory cluster analysis on the first set. The results of the initial clustering and validation follow.

\subsection{Development and Description of Clusters}


In this sub-section we present the results from the clustering. The validation of the findings is discussed in the next section. Table 2 provides the overall results of the one-way ANOVA for the clusters based on revenue sources. As expected, since the clusters were defined by revenue sources, for all revenue sources the mean percents were significantly different by cluster. However, we were interested in how well the group means separated out by revenue source(s). We therefore examined the results of the Post Hoc tests (Tukey's) to see whether the clusters fell into distinct groupings with respect to the revenue types. For example, from Table 2, we see that the revenue source "sponsorships" clearly separates the 5 clusters into two groups, which could be called high versus low levels of sponsorship, because there is no statistical overlap in the means. Considering all revenue sources, the Post Hoc tests indicate no more than one cluster overlapping for any comparison. This fits the requirements stated above to have group means that are very different, as well as small standard deviations within each cluster to establish a statistical difference. Thus we can conclude that each revenue type splits the file of charities into distinct groups of clusters.

\section{[INSERT TABLE 2 HERE]}

The next question is whether a consideration of all the revenue types together defines meaningful distinct clusters. Table 3 shows the means and standard deviations of the revenue sources by Revenue Cluster and provides names for each of these clusters. From Table 3, it can be seen that for each Revenue Source, one mean is clearly larger than the others (often several times larger). We can therefore say that the Revenue Clusters reflect different dominant revenue sources. Because of this, we have named the clusters according to their dominant revenue source. We called Cluster 1 the "Classic Charity" Cluster as $85.06 \%$ of its revenue is derived from public donations and $6.26 \%$ from goods and services - a total of $91.32 \%$ of income from these sources ( $S D=11.80)$. Further, Cluster 2 was named "Service Providers" as $89.10 \%$ of their income also derived from these combined sources $(S D=12.82)$, but there was a much lower percentage (16.48\%) from public donations, with the majority of their revenue (72.42\%) being derived from goods and services. The revenues of the cluster were not widely diversified, except for the Cluster 3 charities which we termed "Member Organizations" and which had more diverse revenue sources. It can be observed from Tables 4 and 5 (below) that, although the clusters were defined on the basis of revenue, there were statistically significant differences in mean expenditures and in mean assets and liabilities. They are as follows:

- Cluster 1: Classic charities: receive the great majority of their income from public donations. They are differentiated from membership organizations and service providers, as they focus on charitable support, rather than members and services alone. They are second only to service 
providers in their expenditure on staff and services. In addition, classic charities have the most cash assets of all the charities identified in this taxonomy.

- Cluster 2: Service providers: receive most funds for delivering goods and services for government and expend most of their funds on services and staffing. Service providers are most likely to have short term loans - these will include creditors, staff accruals, and short term leasing arrangements, however they also hold a large percentage of their assets in cash, especially when compared to the member-based, infrastructure and trusts/grantor charities.

- Cluster 3: Member organizations: their main forms of income are from membership and sponsorship and, for the charities analysed, these were the main recipients of bequests (although it is not a large percentage of total income). In addition, these charities record the highest overhead expenditure of all the charity clusters and make the least amount of grants.

- Cluster 4: Infrastructure providers: provide facilities, structures and systems to support and coordinate front-line service organizations so that they in turn can deliver their missions more effectively. For example, these might be accommodation for a service, a campsite or community hall. These charities receive the majority of their income from rents and their expenditure on financing confirms their difference from other clusters. They are the largest owners of Property, Plant and Equipment and are most likely to have loans from members and other sources.

- Cluster 5: Trusts/Grantors: have the most short term investments and receive the majority of their funds from these investments. They also pay out the most grants and have low expenditure on other classifications such as staff and overheads.

\section{[INSERT TABLE 3 HERE]}

To achieve a visual representation of the distribution of the charities, we plotted the data using Multidimensional Scaling (MDS). MDS is a way of representing the distances or dissimilarities between cases into two- or three- dimensional space, as defined by the variables specified. For example, the MDS plot of the charities based on the revenue percent variables (Bequests, Goods and Services, Investment income, Membership, Public Donations, Rental, Sponsorship), considers how dissimilar the charities are from each other, based on the different values of these variables. In our case, a Euclidean metric was used (as was used in the cluster analysis). Once the charities data had been mapped (in eight revenue dimensions and viewed in two-dimensional space), they were labelled by their cluster. We could then determine visually whether or not the charities in the same cluster were close together with respect to these variables. The MDS plot of these variables identified by cluster is shown in Figure 1. 


\section{[INSERT FIGURE 1 HERE]}

The MDS plot in Figure 1 separates out the clusters quite well in two-dimensional space. That is to say, the clusters as defined have quite different patterns of revenue. None of these clusters is far away from the others, but they are distinct. Table 3 clearly describes the differences in means between the Revenue Clusters. However, we also sought to ascertain whether there was a difference in other financial elements based on cluster type. The analysis of variance results in Table 4 show that the revenue-based clusters also have different means for the expenditure variables. While they are not as marked as the difference in the revenue variable means, it can be seen that the patterns of expenditure map to the Revenue Clusters. These differences are further elaborated on in the definitions of the clusters above.

\section{[INSERT TABLE 4 HERE]}

Table 5 presents the means and standard deviations of charities' assets and liabilities variables by Revenue Cluster. This also shows that there are differences in the clusters as they are defined (specifically in terms of investments in Trusts/grantors, Property, Plant and Equipment and Long-term borrowing by Infrastructure providers.

[INSERT TABLE 5 HERE]

\subsection{Validation of the Revenue Clusters}

As noted above, it is good practice to validate the cluster algorithm with a second data set (Tan et al., 2004). This confirmatory set (296 different registered charities) was clustered according to the Revenue Clusters defined on the original data set of 803 charities (see Table 3 above). We found very similar patterns of revenues, expenditures, assets and liabilities by cluster. For example, classic charities (Cluster 1 ) in the original 803 received $85.06 \%$ revenue from public/donations (see Table 3 ) and the similar cluster from the new 296 received 85.21\% revenue from the same source (the highest of the clusters). Further, Table 3 shows that service providers (Cluster 2 ) in the original 803 received 72.42\% revenue from goods and services and the similar cluster from the new 296 charities received $73.43 \%$ revenue from goods and services (again, the highest of all the clusters), while trusts/grantors (Cluster 5 ) in the original 803 received $92.20 \%$ revenue from investment and the similar cluster from the new 296 received $92.64 \%$ from investment.

The same held true for expenditures in the confirmatory data set (of 296). Service providers (Cluster 2) in the original 803 expended $36.25 \%$ on services (see Table 4 ) and the similar cluster from the new 296 charities expended $34.95 \%$ on services. Further, Table 4 shows that $41.66 \%$ of 
trusts/grantors' (Cluster 5) expenditure in the original 803 was on grants and the similar cluster from the new 296 expended $42.60 \%$ on grants.

With respect to assets and liabilities, service providers (Cluster 2) and classic charities (Cluster 1) in the original 803 recorded $41.26 \%$ and $49.42 \%$ cash assets respectively (see Table 5 ) and the similar clusters from the new 296 charities recorded $41.41 \%$ and $37.45 \%$ in cash assets respectively. The mean for social services was almost identical; however, classic charities held slightly less in the simple random sample of 296 than the stratified sample of 803 charities. Further, Table 5 shows that in the original 803 infrastructure providers (Cluster 4) hold 65.81\% of their assets in Property, Plant and \& Equipment (PP\&E) and the similar cluster from the new 296 held $45.29 \%$ in PP\&E. Finally, trusts/grantors (Cluster 5) in the original 803 held $67.69 \%$ in investments (see Table 5) and the similar cluster from the new 296 charities held $65.70 \%$ in investments.

This consistency in patterns of revenue, expenditure, assets and liabilities between the two different data sets suggest that this method of grouping charities is robust and reflects a repeatable pattern in New Zealand charities. Further analysis of the charities within each cluster was undertaken to estimate the percentages within the population of regulated organizations. We used the second sample of 296 charities (used to validate the clustering, as discussed in section 5.2), which was a simple random sample of regulated charities in New Zealand. The standard 95\% confidence interval for a proportion was used and is shown in Table 6. This data is now discussed.

\subsection{A schema for classifying organizations subject to public regulation}

From the regulation theory literature reviewed, we expect that the types of charities that would benefit most from regulation and which government would be most interested in regulating would be those that provide public goods and grow philanthropy. Governments would be most interested to ensure that these charities are eligible for their exemptions from income tax and that the tax credits that donors can claim are worthwhile. Charities providing public goods will be those that receive high levels of public donations (and therefore arise from market failure, as argued by Rose-Ackerman, 1986) and they will benefit from published financial statements (Gordon \& Khumawala, 1999). These were identified by the cluster analysis as Cluster 1 ("Classic Charities").

There is also an argument that charities that are government funded to provide social services require regulatory monitoring (as Weisbrod, 1988 argues, these arise to reduce government failure). These were identified by the cluster analysis as Cluster 2 ("Service Providers"). Alternatively, government service purchasers have an intense interest in service providers and differentiated regulation could leave oversight of these charities to the principal. Indeed, Verbruggen et al (2011) 
believed a government funder would more closely monitor charities than a donor public. Nevertheless, there may be multiple government agencies funding a specific charity and therefore we believe that when government funds a charity regulator as well as service providers, it should empower that regulator to undertake monitoring on its behalf as this would achieve regulatory efficiency.

\section{[INSERT TABLE 6 HERE]}

As shown in Table 6, this research showed that Cluster 1 ("Classic Charities") and Cluster 2 ("Service Providers") total only between $67.94 \%$ and $78.06 \%$ of all registered (regulated) charities (73 $\pm 5.06 \%$ ). On the other hand, the three other clusters (Cluster 3: "Member Organizations"; Cluster 4 "Infrastructure Providers"; Cluster 5: "Trusts/grantors") receive low levels of revenue from public donations and public funding of goods and services. These "types" have arisen due to contract failure and/or to increase social capital (as hypothesized by Ben-Ner, 1986; Bryce, 2005). Their main resource providers are more concentrated than the general public and they are likely to be legally empowered to monitor these charities (Mayer \& Wilson, 2010). It therefore appears that government regulation of charities in clusters 3,4 and 5 is a duplication of resources. In addition, we found that the regulator's tight operating budget, increasing donation rebates, and government funding into the sector are juxtaposed against a rising number of public complaints about charities, as well as regulator audits, suggest declining public trust and confidence. The New Zealand case is an example of the need to find cost efficiencies, so that the regulator can focus on improving charity accountability. Further, as argued by Mayer and Wilson (2010) and implied by Palmer (2013), efficiencies in regulation will ease the burden of regulation on small charities (an argument also supported by public choice theory; Peltzman, 1976).

We noted earlier that differentiated regulation has been used as a policy tool in some industries. In electricity regulation, consumer-owners monitor the prices and quality of their own electricity distribution business in the manner described by Ben-Ner (1986). In that example, differentiated regulation has reduced the cost of monitoring as the regulator can fully audit and respond to complaints about a smaller number of organizations (those that meet its brief) and leave other (legally empowered) stakeholders to monitor the organizations which are not required to be fully regulated. It can be expected that the stakeholders of charities in clusters 3, 4 and 5 would monitor them in any case, but when regulatory resources are duplicated, these stakeholders receive false comfort from believing government also actively regulates these charities. 
Differentiated regulation could be useful when members predominate in a charity and they also enjoy the goods and services it provides. These members are unlikely to need a regulator in order to access financial and other data from charities which they fund (these would be Cluster 3: "Member Organizations"). When members fund and manage interdependent (mutual) nonprofit entities, they are legally able to demand financial reporting from these organizations (Hansmann, 1986). It has been argued that such stakeholder management will be of a higher quality than that provided by the regulator alone (Breen, 2013; Freeman, 1984; Yetman \& Yetman, 2012) and this is underpinned by the empirical evidence from, for example, Cleveland and Krashinsky (2009). While a shortcoming of depending on member regulation may be that members may choose rational ignorance and fail to monitor; if members are unhappy with the charity's management, they can exit by resigning and not paying their membership fees. As shown in Table 6, between $5 \%$ and $11.2 \%$ of registered charities are member organizations $(8.1 \pm 3.11 \%)$. In line with Hansmann (1986) and Ben-Ner (1986), we argue that the members should already regulate these charities and that the rise of a public regulator has potentially reduced members' effort with detrimental effects on public trust and confidence.

In respect of two other clusters (4: "Infrastructure Providers and 5: "Trusts/grantors"), it is also apparent that donors and funders of goods and services are not the prime resource providers. Government's regulatory effort is likely to have sent the wrong signal to stakeholders of entities which do not arise from market or government failure. Infrastructure providers represent $0.35 \%-5.85 \%$ $(3.7 \% \pm 2.15 \%)$ of the population and the trusts/grantors are represent $10.91 \%-19.29 \%(15.2 \% \pm$ $4.09 \%)$ of the population. They receive funds from rental and investments respectively and are managed in terms of their trust deeds. In respect of investment income, Kreander, Beattie and McPhail (2009) confirm that organizations with investment funds should be closely monitored by their boards. For infrastructure organizations, their boards and management should also monitor rental revenue. Combined with member organizations, infrastructure providers and trusts/grantors represent between $21.94 \%$ and $32.06 \%$ of the total population.

\section{Conclusion}

Public trust and confidence in charities has declined and yet significant resources continue to be committed to the sector (Slack \& Leung-Wai, 2007). The extent of resources used by these agents has given rise to calls for regulation in the public interest (Ferguson, 2005; Gaskin, 1999). Yet, regulatory effort and monitoring is progressively resource-constrained. We recommend differentiated regulation as a way to increase regulatory efficiency by active monitoring of only the subset of charities which provide public goods and philanthropy. We also argue that it is probably efficient for 
government to regulate its social services providers, but recognise that multiple-agent contracting requires more resources and a single regulator may bring efficiency to this scenario.

We demonstrate differentiated regulation's feasibility by analysis of data on registered charities in New Zealand to show that charities do fall into distinct types. That is, despite the expectation that charities would have a portfolio of diverse funding (to ensure sustainability), most charities receive a majority of their revenues from a discrete number of resources. We found that around 27 percent of the organizations do not receive significant funding from either donations nor charitable goods and services delivery. Around 8 percent of the organizations are member-based and the remaining 19 percent of registrations are infrastructure providers and trusts/grantors. These groups could be eliminated from the focus of the regulator and hence enable the regulator to focus its slim resources on the remaining $73 \%$ of charities that require regulatory oversight.

The population from which the sample was chosen covers 95.96 percent of the total number of registered charities in New Zealand and presents probably the biggest regulatory challenge due to their diversity (Mayer \& Wilson, 2010). Their profile is similar to that in other countries, for example Canada (Phillips, 2013), England and Wales and Ireland (Breen, 2013) and the US (Mayer \& Wilson, 2010). Hence, we are unaware of specific contextual factors that would make these New Zealand charities markedly different from their counterparts in other Anglo-American countries at least. Therefore, this analysis of disclosure-based regulation of charities based on a rational of resource provision rather than size could be applied by both older regulators (for example US, England and Wales) and newer regulators. Certainly research in these areas to analyse the feasibility of such differentiation, combined with how to reduce any limitations of self-regulation, are welcomed. In particular, specific analysis of the financing reporting and auditing needs of the monitoring stakeholders, will be required.

Refocusing regulatory effort to reflect differentiated regulation principles to reinstate the onus on members to monitor, could also reduce charities' compliance costs. More importantly, this strategy would enable the regulator to re-focus its scarce resources and increase effort on those charities that receive a majority of their funds from donations and/or publicly-funded service provision. Within this, size-related exemptions could also continue to be utilised to further manage the cost-benefit trade-off. Following such a re-focus, the regulator would be better placed to achieve its aim to promote the public interest, and public trust and confidence in registered charities might increase, otherwise regulation is destined to be yet another expensive example of public choice failure. 


\section{CASES:}

Commissioners for Special Purposes of the Income Tax v. John Frederick Pemsel [1891] AC 531.

\section{REFERENCES:}

Abramson, A. J., Salamon, L. M., \& Steurle, C. E. (2006). Federal spending and tax policies: their implications for the nonprofit sector. In E. T. Boris \& C. E. Steurle (Eds.), Nonprofits and government: collaboration and conflict (pp. 107-138). Washington DC: The Urban Institute Press.

Accounting Standards Review Board. (2007). Delay of the Mandatory Adoption of New Zealand Equivalents to International Financial Reporting Standards for Certain Small Entities (p. 4).

Australian Government Department of Social Services. (2014). Australia's Charities and Not-for-Profits Consulatation Report (p. 12). Canberra, ACT.

Ben-Ner, A. (1986). Nonprofit Organizations: Why do they exist in market economies? In S. Rose-Ackerman (Ed.), The Economics of Nonprofit Institutions: Studies in Structure and Policy (pp. 94-113). New York: Oxford University Press.

Breen, O. B. (2009). Regulating Charitable Solicitation Practices - the search for a hybrid solution. Financial Accountability \& Management, 25(1), 115-143.

Breen, O. B. (2013). The Disclosure Panacea: A Comparative Perspective on Charity Financial Reporting. Voluntas: International Journal of Voluntary and Nonprofit Organizations, 24(3), 852-880. doi:10.1007/s11266-013-9377-2

Breen, O. B., Ford, P., \& Morgan, G. G. (2009). Cross-Border Issues in the Regulation of Charities: Experiences from the UK and Ireland. International Journal of Not-forProfit Law, 11(3), 5-41.

Bryce, H. J. (2005). Players in the Public Policy Process: Nonprofits as Social Capital and Agents (p. 271). New York, NY: Palgrave Macmillan.

Chalmers, K., Godfrey, J. M., \& Lynch, B. (2012). Regulatory theory insights into the past, present and future of general purpose water accounting standard setting. Accounting, Auditing \& Accountability Journal, 25(6), 1001-1024. doi:10.1108/09513571211250224

Charities Commission. (2012). Annual Report 2011/2012 (p. 53).

Christensen, T., \& Lægreid, P. (2006). Agentification and Regulatory Reforms. In T. Christensen \& P. Lægreid (Eds.), Autonomy and regulation. Coping with agencies in the modern state (pp. 8-49). Cheltenham, UK: Edward Elgar Publishing Limited.

Cleveland, G., \& Krashinsky, M. (2009). The Nonprofit Advantage: Producing Quality in Thick and Thin Child Care Markets. Journal of Policy Analysis and Management, 28(3), 440-462. doi:10.1002/pam 
Connolly, C., \& Hyndman, N. (2013). Towards Charity Accountability: Narrowing the gap between provision and needs? Public Management Review, 15(7), 945-968. doi:10.1080/14719037.2012.757349

Cordery, C. J. (2013). Regulating Small and Medium Charities: Does It Improve Transparency and Accountability? Voluntas: International Journal of Voluntary and Nonprofit Organizations, 24(3), 831-851. doi:10.1007/s11266-013-9381-6

Cordery, C. J., \& Patel, K. (2011). Financial Reporting Stocktake: An Assessment of Accountability through Charities' Filings on New Zealand's Charities Register. Wellington: Victoria University of Wellington.

Crawford, L., Morgan, G. G., Cordery, C. J., \& Breen, O. B. (2014). International financial reporting for the not-for-profit sector: a study commissioned by the CCAB (p. 137). London, UK.

Dalton, B., \& Casey, J. (2008). Money for mission or moral midefield? The opportunities and risks of not-for-profit bsuiness venturing. In J. Barraket (Ed.), Strategic Issues for the not-for-profit sector (p. 256). Sydney: UNSW Press.

Department of Internal Affairs. (2007). A survey of Government funding of non-profit organisations (p. 40). Wellington: Department of Internal Affairs.

Desai, A. M., \& Yetman, R. J. (2005). Constraining managers without owners: governance of the not-for-profit enterprise (p. 39). Cambridge, MA: National Bureau of Economic Research.

Ferguson, A. (2005). Charity Cases. Business Review Weekly, (March 24-30), 44-55.

Freeman, R. E. (1984). Strategic Management: A Stakeholder Approach. Boston: Pitman Publishing.

Fries, R. (2003). The Charities Commission: The Concept in the Light of English Experience. Philanthropy New Zealand Magazine, 2(34), 8-9.

Gaskin, K. (1999). Blurred vision: public trust in charities. International Journal of Nonprofit and Voluntary Sector Marketing, 4(2), 163-178.

Gibelman, M., \& Gelman, S. R. (2004). A Loss of Credibility: Patterns of Wrongdoing Among Nongovernmental Organizations. VOLUNTAS: International Journal of Voluntary and Nonprofit Organizations, 15(4), 355-381. doi:10.1007/s11266-0041237-7

Gordon, T. P., \& Khumawala, S. B. (1999). The demand for not-for-profit financial statements: a model of individual giving. Journal of Accounting Literature, 18, 31-56.

Gousmett, M. (2009). The Charitable Purposes Exemption from Income Tax: Pitt to Pemsel 1798 - 1891. Canterbury. 
Griffin, P. A., Lont, D. H., \& Sun, Y. (2009). Governance regulatory changes , International Financial Reporting Standards adoption, and New Zealand audit and non-audit fees : empirical evidence. Accounting and Finance, 49(April), 697-724.

Gruenspecht, H. K. (1982). Differentiated Regulation: The Case of Auto Emissions Standards. The American Economic Review, 72(2), 328-331.

Hansen, H. F., \& Pedersen, L. H. (2005). The Dynamics of Regulatory Reform. In Autonomization of the state: From integrated administrative models to single purpose organizations (pp. 1-22). California, USA: Stanford University.

Hansmann, H. B. (1986). The role of nonprofit enterprise. In S. Rose-Ackerman (Ed.), The Economics of Nonprofit Institutions: Studies in Structure and Policy (Vol. 89, pp. 5784). New York: Oxford University Press.

Hofmann, M. A., \& McSwain, D. (2013). Financial disclosure management in the nonprofit sector: A framework for past and future research. Journal of Accounting Literature, 32(1), 61-87. doi:10.1016/j.acclit.2013.10.003

Horizon Research. (2014). Public Trust and Confidence in Charities (p. 95). Auckland. Retrieved from http://eprints.uwe.ac.uk/15405/

Hyndman, N., \& McMahon, D. (2011). The hand of government in shaping accounting and reporting in the UK charity sector. Public Money and Management, 31(3), 167-173.

Irvine, H., \& Ryan, C. (2013). Accounting regulation for charities: international responses to IFRS adoption. Pacific Accounting Review, 25(2), 124-144. doi:10.1108/PAR-032012-0009

James, E. (1987). The Nonprofit Sector in Comparative Perspective. In W. W. Powell (Ed.), The Nonprofit Sector: a Research Handbook (pp. 397-415). New Haven, CT: Yale University Press.

Keating, E. K., \& Frumkin, P. (2003). Reengineering Nonprofit Financial Accountability: Toward a More Reliable Foundation for Regulation. Public Administration Review, 63(1), 3-15.

Kitching, K. (2009). Audit value and charitable organizations. Journal of Accounting and Public Policy, 28(6), 510-524. doi:10.1016/j.jaccpubpol.2009.08.005

Kreander, N., Beattie, V., \& McPhail, K. (2009). Putting our money where their mouth is: Alignment of charitable aims with charity investments - Tensions in policy and practice. The British Accounting Review, 41(3), 154-168. doi:10.1016/j.bar.2009.06.001

Leone, A. J., \& Van Horn, R. L. (2005). How Do Nonprofit Hospitals Manage Earnings? Journal of Health Economics, 24(4), 815-837. Retrieved from http://www.sciencedirect.com/science/article/B6V8K-4G65C09-

1/2/f2a793c89ab411245109d1e3890ecf18 
Lyons, M. (2001). Third Sector: The contribution of nonprofit and cooperative enterprises in Australia. Sydney: Allen \& Unwin.

Mayer, L. H., \& Wilson, B. M. (2010). Regulating charities in the twenty-first century: an institutional choice analysis. Chicago-Kent Law Review, 85(2), 479-530.

Morgan, G. G. (2013). Charitable Incorporated Organisations (p. 366). London: Directory of Social Change.

New Zealand Government. Commerce Act (1986). Wellington, New Zealand: New Zealand Government.

New Zealand Government. Charities Act 2005 (2012).

New Zealand Working Party on Charities and Sporting Bodies. (1989). New Zealand Working Party on Charities and Sporting Bodies. Wellington.

Newell, H. (1997). Accountabiilty of Charities and Sporting Bodies Working Party Comprehensive Report (p. 43). Wellington, New Zealand.

Peitz, M. (2005). Asymmetric access price regulation in telecommunications markets. European Economic Review, 49(2), 341-358. doi:10.1016/S0014-2921(03)00046-1

Peltzman, S. (1976). Toward a more general theory of regulation. Journal of Law and Economics, 19(2), 211-240.

Phillips, S. D. (2013). Shining Light on Charities or Looking in the Wrong Place? Regulation-by-Transparency in Canada. VOLUNTAS: International Journal of Voluntary and Nonprofit Organizations, 24(3), 881-905. doi:10.1007/s11266-0139374-5

Posnett, J., \& Sandler, T. (1989). Demand for Charity Donations in Private Non-Profit Markets: The Case of the U.K. Journal of Public Economics, 40, 187-200.

Productivity Commission. (2010). Contribution of the Not-for-Profit Sector: Research Report (p. 504). Canberra: Productivity Commission.

Reheul, A.-M., Caneghem, T., \& Verbruggen, S. (2014). Financial Reporting Lags in the Non-profit Sector: An Empirical Analysis. Voluntas: International Journal of Voluntary and Nonprofit Organisations, 25(2), 352-377. doi:10.1007/s11266-0129344-3

Robbins, G., \& Lapsley, I. (2008). Irish voluntary hospitals: An examination of a theory of voluntary failure. Accounting, Business and Finanical History, 18(1), 61-80.

Rose-Ackerman, S. (1986). The Economics of Nonprofit Institutions: Studies in Structure and Policy. (S. Rose-Ackerman, Ed.)Yale Studies on Nonprofit Organizations. New York, NY: Oxford University Press. 
Saj, P. (2014). A Critique of the Majority Report of the Senate Economics Legislation Committee Review of the Australian Charities and Not-for-profits Commission ( Repeal ) ( No . 1 ) Bill 2014 ( Provisions ). Third Sector Review, 20(2), 107-137.

Salamon, L. M. (1987). Of market failure, voluntary failure, and third-party government: Toward a theory of government-nonprofit relations in the modern welfare state. Journal of Voluntary Action Research, 16(1-2), 29-49.

Salamon, L. M. (1990). The Nonprofit Sector and Government: The American Experience in Theory and Practice. In H. K. Anheier \& W. Seibel (Eds.), The Third Sector: Comparative Studies of Nonprofit Organisations (pp. 219-240). Berlin: Walter de Gruyter \& Co.

Salamon, L. M. (1995). Partners in public service: government-nonprofit relations in the modern welfare state (p. 310). Baltimore MD: The Johns Hopkins University Press.

Salamon, L. M., \& Anheier, H. K. (1992a). In search of the non-profit sector II The problem of classification. Voluntas: International Journal of Voluntary and Nonprofit Organizations, 3(3), 267-309.

Salamon, L. M., \& Anheier, H. K. (1992b). In search of the non-profit sector. I: The question of definitions. Voluntas: International Journal of Voluntary and Nonprofit Organizations, 3(2), 125-151. doi:10.1007/BF01397770

Simon, J. G. (1995). The regulation of American foundations : looking backward at the Tax Reform Act of 1969. Voluntas: International Journal of Voluntary and Nonprofit Organizations, 6(3), 243-254.

Sinclair, R., Northcott, D., \& Hooper, K. (2014). Can Sector-specific Standards Enhance the Comparability of Third Sector Organisations ' Financial Statements ? Third Sector Review, 20(2), 27-55.

Slack, A., \& Leung-Wai, J. (2007). Giving New Zealand: Philanthropic Funding 2006. (B. and E. R. Limited, Ed.) (p. 66). Wellington: Philanthropy New Zealand.

Smith, G. P. (2012). Capital Structure Determinants for Tax-Exempt Organisations: Evidence from the UK. Financial Accountability and Management, 28(May), 143-163.

Solomons, D. (1978). The politicization of accounting. Journal of Accountancy, 146(Nov.), 65-72.

Stavin, R. N. (2006). Value-Differentiated Environmental Regulation. Stanford Environmental Law Journal, 29, 29-66.

Stigler, G. J. (1971). The theory of economic regulation. The Bell Journal of Economics and Management Science, 2(1), 3-21. 
Sutton, D. B., Baskerville, R. F., \& Cordery, C. J. (2010). A development agenda, the donor dollar and voluntary failure. Accounting, Business \& Financial History, 20(2), 209229.

Tan, P.-N., Steinbach, M., \& Kumar, V. (2004). Cluster Analysis : In Introduction to Data Mining (pp. 487-568). Addison-Wesley.

Verbruggen, S., Christiaens, J., \& Milis, K. (2011). Can Resource Dependence and Coercive Isomorphism Explain Nonprofit Organizations' Compliance With Reporting Standards? Nonprofit and Voluntary Sector Quarterly, 40(2), 5-32.

Weisbrod, B. A. (1988). The Nonprofit Economy (p. 251). Cambridge, MA: Harvard University Press.

Weisbrod, B. A. (1989). Rewarding Performance That is Hard to Measure: The Private Nonprofit Sector. Science, 244(4904), 541-546. Retrieved from http://proquest.umi.com/pqdweb?did=1790645\&Fmt=7\&clientId=7511\&RQT=30 9\&VName $=\mathrm{PQD}$

Weisbrod, B. A., \& Dominguez D., N. (1986). Demand for collective goods in private nonprofit markets: Can fundraising expenditures help overcome free-rider behavior? Journal of Public Economics, 30, 83-95.

Williams, D. J. (1984). Regulating the accountability of charitable institutions. Accounting and Finance, 24(1), 1-15.

Working Party on Registration Reporting and Monitoring of Charities. (2002). Report by the Working Party on Registration, Reporting and Monitoring of Charities. Wellington.

Yetman, M. H., \& Yetman, R. J. (2012). The Effects of Governance on the Accuracy of Charitable Expenses Reported by Nonprofit Organizations. Contemporary Accounting Research, 29(3), 738-767. doi:10.1111/j.1911-3846.2011.01121.x

Young, D. R., \& Grinsfelder, M. C. (2006). Social Entrepreneurship and the Financing of Third Sector Organizations. Journal of Public Affairs Education, 17(4), 543-567. 
Table 1: Comparison of general charities regulators, number of charities and costs as at April $2014^{1}$

\begin{tabular}{|c|c|c|c|c|}
\hline $\begin{array}{l}\text { Country \& Regulator } \\
\text { name }\end{array}$ & $\begin{array}{l}\text { \# } \\
\text { registered } \\
\text { charities }\end{array}$ & $\begin{array}{l}\text { Direct Cost of } \\
\text { regulator (local } \\
\text { currency/ US\$) }\end{array}$ & $\begin{array}{l}\text { Direct Cost (in US\$) } \\
\text { divided by \# } \\
\text { charities }\end{array}$ & Filing requirements \\
\hline $\begin{array}{l}\text { Australia (Australian } \\
\text { Charities and Not- } \\
\text { for-profits } \\
\text { Commission) }\end{array}$ & $\begin{array}{l}60,000 \\
\text { expected } \\
(1,643 \\
\text { currently) }\end{array}$ & $\begin{array}{l}\text { AU\$14m } \\
\text { US\$12.8m) }\end{array}$ & $\begin{array}{l}\text { US\$213 ( per } \\
\text { expected number) } \\
\text { US\$7,790 per } \\
\text { current registrations }\end{array}$ & $\begin{array}{l}\text { From } 2014 / 5 \text { charities with annual revenue of }>A U \$ 250,000 \text { must file } \\
\text { financial statements along with their other information. Religious } \\
\text { charities are exempt from registering. However, the Australian Charities } \\
\text { and Not-for-Profits Commission (Repeal) (No 1) Bill } 2014 \text { plans to } \\
\text { disestablish the regulator. }\end{array}$ \\
\hline $\begin{array}{l}\text { Canada (Canada } \\
\text { Revenue Agency) }\end{array}$ & 86,000 & $\begin{array}{l}\text { CAN\$29.6m } \\
\text { (US\$27.06m) }\end{array}$ & US\$315 & $\begin{array}{l}\text { All charities must register for charitable status and file financial } \\
\text { statements and other information (Crawford et al., 2014). }\end{array}$ \\
\hline $\begin{array}{l}\text { England and Wales } \\
\text { (Charity Commission } \\
\text { for England and } \\
\text { Wales) }\end{array}$ & 165,000 & $\begin{array}{l}\text { f20m } \\
\text { (US\$32.4m) }\end{array}$ & US\$196 & $\begin{array}{l}\text { Most charities must register (unless excepted due to having e.g. } \\
<£ 5,000 \text { in income), charities that are regulated in other ways are } \\
\text { exempted. Otherwise, if a charity's income is }<£ 25,000 \text { in the year, they } \\
\text { must file financial statements (Morgan, 2013). }\end{array}$ \\
\hline $\begin{array}{l}\text { Ireland (Charities } \\
\text { Regulatory } \\
\text { Authority) }\end{array}$ & $\begin{array}{l}8,200 \\
\text { expected }(0 \\
\text { currently) }\end{array}$ & $\begin{array}{l}€ 1 \mathrm{~m} \\
\text { (US\$1.29m) }\end{array}$ & $\begin{array}{l}\text { US\$161 ( per } \\
\text { expected number) }\end{array}$ & $\begin{array}{l}\text { All charities must register for charitable status - however due to the } \\
\text { very recent establishment, education charities are currently exempted. } \\
\text { Registered charities must file financial statements and other } \\
\text { information. }^{2}\end{array}$ \\
\hline $\begin{array}{l}\text { New Zealand (was } \\
\text { Charities } \\
\text { Commission, now } \\
\text { Charities Services) }\end{array}$ & 27,000 & $\begin{array}{l}\mathrm{NZ \$ 6.3m} \\
\text { (US\$5.18m) }\end{array}$ & US\$192 & $\begin{array}{l}\text { All charities must register to receive benefits. They must also file } \\
\text { financial statements and other information. New cash and accrual } \\
\text { accounting standards are applicable from } 1 \text { April } 2015 \text { (Crawford et al., } \\
\text { 2014). }\end{array}$ \\
\hline $\begin{array}{l}\text { Scotland (Office of } \\
\text { the Scottish Charity } \\
\text { Regulator) }\end{array}$ & 23,800 & $\begin{array}{l}\text { f3.05m } \\
(\text { US\$4.94m)) }\end{array}$ & US\$208 & $\begin{array}{l}\text { All charities must register and file financial statements. Some } \\
\text { designated religious charities are more lightly regulated under the Act } \\
\text { (Morgan, 2013). }\end{array}$ \\
\hline $\begin{array}{l}\text { Singapore } \\
\text { (Singapore } \\
\text { Commissioner of } \\
\text { Charities) }\end{array}$ & 2,130 & $\begin{array}{l}\text { SING\$6.4m } \\
\text { (US\$5.07m) }\end{array}$ & US\$2,380 & $\begin{array}{l}\text { Registration is voluntary but necessary for "Institutions of a Public } \\
\text { Character" (those wanting to issue tax-deductible donation receipts). } \\
\text { All registered organizations must file financial statements. There are } \\
\text { special requirements for those with expenditure }>\$ 500,000 .^{3}\end{array}$ \\
\hline
\end{tabular}

Note 1: Information from Australian Charities and Not-for-profits Commission International charity regulators' meeting downloaded from the internet http://www.acnc.gov.au/ACNC/Pblctns/Rpts/IntReg/ACNC/ Publications/Reports/InternationalReg.aspx?noleft=1 
Note 2: Information from the Charity Regulatory Authority downloaded from the internet https://www.charitiesregulatoryauthority.ie/Website/ CRA/CRAweb.nsf/ page/whatwedo-annualreporting-en

Note 3: Information from the Singapore Commissioner of Charities downloaded from the internet https://www.charities.gov.sg/manage-yourcharity/Annual\%20Submission/Pages/Annual\%20Report.asp. 
Table 2: Results of ANOVA comparison of means by Revenue Cluster.

\begin{tabular}{llll}
\hline Revenue Type & Overall F statistic & p-value & Post Hoc result: range of cluster means \\
\hline Public/ Donations & 1218.174 & 0.000 & 4 groups, 1,1,0 overlap: 3.56\%-85.06\% \\
Sponsorships & 10.615 & 0.000 & 2 groups, no overlap; 0.00\% - 4.99\% \\
Goods and services & 991.920 & 0.000 & 3 groups, 1 overlapping: $1.20 \%-72.42 \%$ \\
Bequests & 9.581 & 0.000 & 2 groups: no overlap: 0.00\%-3.80\% \\
Investments & 2370.176 & 0.000 & 3 groups, no overlap: 3.09\%-92.20\% \\
Gains/ Other & 21.524 & 0.000 & 2 groups, no overlap; $1.28 \%-12.94 \%$ \\
Members & 203.494 & 0.000 & 2 groups, no overlap: 0.42\%- 41.70\% \\
Rental & 1138.88 & 0.000 & 2 groups, no overlap: $0.74-73.43 \%$ \\
\hline
\end{tabular}


Table 3: Means and Standard Deviations of charities' revenue variables by Revenue Cluster

\begin{tabular}{|c|c|c|c|c|c|}
\hline Revenue Type & $\begin{array}{l}\text { Cluster } 1 \\
\text { (Classic } \\
\text { Charity) } \\
\mathrm{N}=395\end{array}$ & $\begin{array}{l}\text { Cluster } 2 \\
\text { (Service } \\
\text { Provider) } \\
\mathrm{N}=\mathbf{2 0 0}\end{array}$ & $\begin{array}{l}\text { Cluster } 3 * * \\
\text { (Member } \\
\text { organization) } \\
\mathrm{N}=64\end{array}$ & $\begin{array}{l}\text { Cluster } 4 \\
\text { (Infrastructure } \\
\text { provider) } \\
\mathrm{N}=\mathbf{3 8}\end{array}$ & $\begin{array}{l}\text { Cluster } 5 \\
\text { (Trust/ } \\
\text { grantor) } \\
\mathrm{N}=106\end{array}$ \\
\hline Public / Donations & $85.06 \%+\dagger$ & $16.68 \%$ & $15.51 \%$ & $9.52 \%$ & $3.56 \% \dagger$ \\
\hline$(p=0.000)^{*}$ & \pm 14.98 & \pm 16.55 & \pm 15.68 & \pm 15.40 & \pm 8.89 \\
\hline Goods \& services & $6.26 \%$ & $72.42 \%+†$ & $11.67 \%$ & $3.96 \%$ & $1.20 \% \dagger$ \\
\hline$(p=0.000)$ & \pm 10.44 & \pm 19.51 & \pm 13.10 & \pm 8.86 & \pm 4.94 \\
\hline Bequests & $0.14 \%$ & $0.0030 \%+$ & $3.80 \%+\dagger$ & $0.0042 \%$ & $0.04 \%$ \\
\hline$(p=0.000)$ & \pm 1.82 & \pm 0.0411 & \pm 15.77 & \pm 0.261 & \pm 0.40 \\
\hline Investments & $3.09 \% \dagger$ & $3.50 \%$ & $8.07 \%$ & $9.33 \%$ & $92.20 \%++$ \\
\hline$(p=0.000)$ & \pm 6.36 & \pm 6.60 & \pm 10.86 & \pm 14.36 & \pm 14.07 \\
\hline Members & $2.13 \%$ & $3.65 \%$ & $41.70 \%+†$ & $0.42 \%^{\dagger}$ & $0.78 \%$ \\
\hline$(p=0.000)$ & \pm 5.67 & \pm 8.07 & \pm 31.69 & \pm 2.48 & \pm 3.65 \\
\hline Rental & $1.54 \%$ & $0.99 \%$ & $1.33 \%$ & $73.43 \%+\dagger$ & $0.74 \% \dagger$ \\
\hline$(p=0.000)$ & \pm 5.15 & \pm 3.42 & \pm 4.67 & \pm 21.38 & \pm 4.29 \\
\hline Sponsorship & $0.36 \%$ & $1.48 \%$ & $4.99 \%+\dagger$ & $0.034 \%$ & $0.00 \% \dagger$ \\
\hline$(p=0.000)$ & \pm 2.05 & \pm 5.70 & \pm 16.70 & \pm 0.21 & \pm 0.00 \\
\hline Other $* * *$ & $1.41 \%$ & $1.28 \% \dagger$ & $12.94 \%+\dagger$ & $3.30 \%$ & $1.48 \%$ \\
\hline$(p=0.000)$ & \pm 4.84 & \pm 4.64 & \pm 28.73 & \pm 10.62 & \pm 5.53 \\
\hline
\end{tabular}

* The $p$-value is from the one-way ANOVA of each revenue source by cluster.

** The membership cluster was very diverse with many charities receiving significant percentage of their revenue from 'other' sources.

*** Other includes revenue designated as "other", "foreign exchange (and other asset revaluation) profits", and "insurance claims".

$+\quad$ Indicates the lowest mean for this variable

$+\dagger \quad$ Indicates the highest mean for this variable 
Table 4: Means and Standard Deviations of charities' expenditure variables by revenue cluster

\begin{tabular}{|c|c|c|c|c|c|}
\hline $\begin{array}{l}\text { Expenditure } \\
\text { Type }\end{array}$ & $\begin{array}{l}\text { Cluster } 1 \\
\text { (Classic } \\
\text { Charity) } \\
\mathrm{N}=394\end{array}$ & $\begin{array}{l}\text { Cluster } 2 \\
\text { (Service } \\
\text { Provider) } \\
\mathrm{N}=\mathbf{2 0 0}\end{array}$ & $\begin{array}{l}\text { Cluster } 3 \\
\text { (Member } \\
\text { organization) } \\
\mathrm{N}=63\end{array}$ & $\begin{array}{l}\text { Cluster } 4 \\
\text { (Infrastructure } \\
\text { provider) } \\
\mathrm{N}=\mathbf{3 8}\end{array}$ & $\begin{array}{l}\text { Cluster } 5 \\
\text { (Trust/ } \\
\text { grantor) } \\
\mathrm{N}=106\end{array}$ \\
\hline \multirow{2}{*}{$\begin{array}{l}\text { Financing** } \\
(p=0.017)^{*}\end{array}$} & $1.70 \%$ & $0.66 \%$ & $0.17 \%^{\dagger}$ & $5.71 \%+\dagger$ & $1.77 \%$ \\
\hline & \pm 9.98 & \pm 2.23 & \pm 0.47 & \pm 14.24 & \pm 11.69 \\
\hline \multirow{2}{*}{$\begin{array}{l}\text { Fundraising } \\
(p=0.000)\end{array}$} & $5.70 \%+\dagger$ & $0.93 \%$ & $3.01 \%$ & $0.50 \%$ & $0.21 \%^{\dagger}$ \\
\hline & \pm 15.41 & \pm 3.51 & \pm 11.20 & \pm 2.70 & \pm 2.02 \\
\hline \multirow{2}{*}{$\begin{array}{l}\text { Grants } \\
(p=0.000)\end{array}$} & $\overline{12.73 \%}$ & $\overline{6} .17 \%$ & $\overline{5} .78 \% \dagger$ & $\overline{9} .49 \%$ & $\overline{4} 1.66 \%+\dagger$ \\
\hline & \pm 28.03 & \pm 16.17 & \pm 18.86 & \pm 21.63 & \pm 42.79 \\
\hline \multirow{2}{*}{$\begin{array}{l}\text { Overhead } \\
(p=0.018)\end{array}$} & $29.87 \%$ & $27.71 \%$ & $38.94 \%+\dagger$ & $30.85 \%$ & $23.53 \% \dagger$ \\
\hline & \pm 29.66 & \pm 24.22 & \pm 31.38 & \pm 26.39 & \pm 33.49 \\
\hline \multirow{2}{*}{$\begin{array}{l}\text { Staff } \\
(p=0.000)\end{array}$} & $20.36 \%+\dagger$ & $17.05 \%$ & $8.16 \%$ & $9.03 \%$ & $1.88 \% \dagger$ \\
\hline & \pm 29.32 & \pm 25.68 & \pm 16.03 & \pm 20.17 & \pm 8.43 \\
\hline \multirow{2}{*}{$\begin{array}{l}\text { Services } \\
(p=0.000)\end{array}$} & $16.06 \%$ & $36.25 \%+\dagger$ & $25.76 \%$ & $12.67 \%$ & $8.22 \% \dagger$ \\
\hline & \pm 24.40 & \pm 29.85 & \pm 27.75 & \pm 20.20 & \pm 22.42 \\
\hline \multicolumn{6}{|c|}{ The $p$-value is from the one-way ANOVA of each expenditure variable by cluster. } \\
\hline \multicolumn{6}{|c|}{ Financing expenditure is spending on interest and leases. } \\
\hline \multicolumn{6}{|c|}{$\dagger \quad$ Indicates the lowest mean for this variable } \\
\hline †† Indicate & ighest me & r this var & & & \\
\hline
\end{tabular}


Table 5: Means and Standard Deviations of charities' asset and liability variables by revenue cluster

\begin{tabular}{|c|c|c|c|c|c|}
\hline $\begin{array}{l}\text { Asset and } \\
\text { Liability } \\
\text { Type }\end{array}$ & $\begin{array}{l}\text { Cluster } 1 \\
\text { (Classic } \\
\text { Charity) } \\
\mathrm{N}=394\end{array}$ & $\begin{array}{l}\text { Cluster } 2 \\
\text { (Service } \\
\text { Provider) } \\
\mathrm{N}=\mathbf{2 0 0}\end{array}$ & $\begin{array}{l}\text { Cluster } 3 \\
\text { (Member } \\
\text { organization) } \\
\mathrm{N}=63\end{array}$ & $\begin{array}{l}\text { Cluster } 4 \\
\text { (Infrastructure } \\
\text { provider) } \\
\mathrm{N}=\mathbf{3 8}\end{array}$ & $\begin{array}{l}\text { Cluster } 5 \\
\text { (Trust/ } \\
\text { grantor) } \\
\mathrm{N}=106\end{array}$ \\
\hline \multicolumn{6}{|l|}{ Assets } \\
\hline Cash & $49.42 \%+\dagger$ & $41.26 \%$ & $34.58 \%$ & $11.82 \% \dagger$ & $22.58 \%$ \\
\hline$(p=0.000)^{*}$ & \pm 39.31 & \pm 37.04 & \pm 38.68 & \pm 25.78 & \pm 35.42 \\
\hline Short Term assets & $5.08 \%$ & $8.21 \%+†$ & $4.08 \%$ & $2.39 \% \dagger$ & $3.41 \%$ \\
\hline$(p=0.033)$ & \pm 14.82 & \pm 18.32 & \pm 13.56 & \pm 8.26 & \pm 14.36 \\
\hline Investments & $17.99 \%$ & $17.59 \% \dagger$ & $36.76 \%$ & $17.61 \%$ & $67.69 \%++$ \\
\hline$(p=0.000)$ & \pm 29.53 & \pm 27.26 & \pm 37.64 & \pm 26.90 & \pm 39.08 \\
\hline Property, Plant \&Equip & $\overline{21} .05 \%$ & $28.56 \%$ & $\overline{18.83 \%}$ & $\overline{6} 5.81 \%+\dagger$ & $\overline{1} .47 \%^{\dagger}$ \\
\hline$(p=0.000)$ & \pm 32.55 & \pm 34.67 & \pm 29.12 & \pm 36.35 & \pm 7.98 \\
\hline \multicolumn{6}{|l|}{ Liabilities } \\
\hline Grants & $8.02 \%+\dagger$ & $6.42 \%$ & $0.95 \%^{\dagger}$ & $2.31 \%$ & $1.24 \%$ \\
\hline$(p=0.005)$ & \pm 24.27 & \pm 19.88 & \pm 7.53 & \pm 11.02 & \pm 10.14 \\
\hline Long-term Borrowing & $\overline{6} .05 \%$ & $\overline{7} .24 \%$ & $\overline{3} .96 \%$ & $\overline{2} 5.38 \%+\dagger$ & $\overline{2} .80 \% \dagger$ \\
\hline$(p=0.000)$ & \pm 21.55 & \pm 22.92 & \pm 17.22 & \pm 40.68 & \pm 16.50 \\
\hline Member Loans & $0.27 \%$ & $0.47 \%$ & $0.00 \% \dagger$ & $2.93 \%+\dagger$ & $1.81 \%$ \\
\hline$(p=0.044)$ & \pm 3.48 & \pm 4.84 & \pm 0.0000 & \pm 14.07 & \pm 13.13 \\
\hline Short Term Liabilities & $\overline{2} 9.86 \%$ & $\overline{33.75 \%+\dagger}$ & $33.82 \%$ & $27.07 \%$ & $\overline{13} .96 \%+$ \\
\hline$(p=0.001)$ & \pm 41.59 & \pm 39.92 & \pm 42.00 & \pm 37.40 & \pm 33.60 \\
\hline
\end{tabular}

* The $p$-value is from the one-way ANOVA of each expenditure variable by cluster.

$+\quad$ Indicates the lowest mean for this variable

$+\dagger$ Indicates the highest mean/s for this variable 
Table 6: Stakeholder-driven regulation model

\begin{tabular}{|c|c|c|c|c|}
\hline \multicolumn{2}{|c|}{ Cluster } & \multirow{2}{*}{$\begin{array}{l}\text { Main funder } \\
\text { Donations }\end{array}$} & \multirow{2}{*}{$\begin{array}{l}\text { Secondary funders } \\
\text { Services, } \\
\text { investments, } \\
\text { members and } \\
\text { rental. }\end{array}$} & \multirow{2}{*}{$\begin{array}{l}\text { Type of regulation } \\
\text { Publicly regulated due } \\
\text { to majority of funding } \\
\text { from donations. }\end{array}$} \\
\hline 1. & $\begin{array}{l}\text { Classic charity } \\
34.1 \% \pm 5.4 \%\end{array}$ & & & \\
\hline 2. & $\begin{array}{l}\text { Service provider } \\
38.9 \% \pm 5.55 \%\end{array}$ & $\begin{array}{l}\text { Funders of goods } \\
\text { and services }\end{array}$ & $\begin{array}{l}\text { Donations, } \\
\text { investments, } \\
\text { members }\end{array}$ & $\begin{array}{l}\text { Publicly regulated due } \\
\text { to government-funded } \\
\text { services. }\end{array}$ \\
\hline 3. & $\begin{array}{l}\text { Member organization } \\
8.1 \% \pm 3.11 \%\end{array}$ & Membership & $\begin{array}{l}\text { Services, sponsors, } \\
\text { investments and } \\
\text { donations }\end{array}$ & $\begin{array}{l}\text { Self-regulated by } \\
\text { member-managers. } \\
\text { (Differentiated) }\end{array}$ \\
\hline 4. & $\begin{array}{l}\text { Infrastructure provider } \\
3.7 \% \pm 2.15 \%\end{array}$ & Rental & $\begin{array}{l}\text { Investments and } \\
\text { donations }\end{array}$ & $\begin{array}{l}\text { Self-regulated by } \\
\text { trustees/management } \\
\text { (Differentiated) }\end{array}$ \\
\hline 5. & $\begin{array}{l}\text { Trust/grantor } \\
15.2 \% \pm 4.09 \%\end{array}$ & Investments & $\begin{array}{l}\text { Donations and } \\
\text { rental }\end{array}$ & $\begin{array}{l}\text { Self-regulated by } \\
\text { trustees } \\
\text { /management. } \\
\text { (Differentiated) }\end{array}$ \\
\hline
\end{tabular}

